\title{
Development of Local Economy through the Strengthening of Small-Medium-Sized Forest Enterprises in KPK, Pakistan
}

\author{
Muhammad Zada ${ }^{1}$, Shagufta Zada ${ }^{2}$, Mudassar Ali ${ }^{3}{ }^{(D}$, Yongjun Zhang ${ }^{1, *}$, Abida Begum ${ }^{2}$, Heesup Han ${ }^{4, *}$ (i), \\ Antonio Ariza-Montes ${ }^{5}$ (D) and Alejandro Vega-Muñoz ${ }^{6}$ (D) \\ 1 Business School, Henan University, Kaifeng 475000, China; mzada@henu.edu.cn \\ 2 Ideological and Political Education Department, School of Marxism, Northeast Forestry University, \\ Harbin 150040, China; shaguftanefu@yahoo.com (S.Z.); abidakhg@gmail.com (A.B.) \\ 3 School of Management, Harbin Institute of Technology, Harbin 150001, China; mudassarsalamat@gmail.com \\ 4 College of Hospitality and Tourism Management, Sejong University, Seoul 05006, Korea \\ 5 Social Matters Research Group, Universidad Loyola Andalucía, C/Escritor Castilla Aguayo, 4, \\ 14004 Córdoba, Spain; ariza@uloyola.es \\ 6 Public Policy Observatory, Universidad Autónoma de Chile, 425 Pedro de Valdivia Avenue, Providencia, \\ Santiago 7500912, Chile; alejandro.vega@uautonoma.cl \\ * Correspondence: 10090055@vip.henu.edu.cn (Y.Z.); heesup@sejong.ac.kr (H.H.)
}

\section{check for} updates

Citation: Zada, M.; Zada, S.; Ali, M.; Zhang, Y.; Begum, A.; Han, H.; Ariza-Montes, A.; Vega-Muñoz, A. Development of Local Economy through the Strengthening of Small-Medium-Sized Forest Enterprises in KPK, Pakistan. Sustainability 2021, 13, 10502. https:/ / doi.org/10.3390/su131910502

Academic Editor: João Carlos Correia Leitão

Received: 3 August 2021

Accepted: 8 September 2021

Published: 22 September 2021

Publisher's Note: MDPI stays neutral with regard to jurisdictional claims in published maps and institutional affiliations.

Copyright: (c) 2021 by the authors. Licensee MDPI, Basel, Switzerland. This article is an open access article distributed under the terms and conditions of the Creative Commons Attribution (CC BY) license (https:/ / creativecommons.org/licenses/by/ $4.0 /)$.

\begin{abstract}
Small-medium-sized forest enterprises (SMFEs) have historically played an essential role in developing countries' economies worldwide because most businesses start as small businesses, and government support and knowledge-based recourse are critical to the sustainable development of SMFEs and local economies. The current studies examined the effects of the Khyber Pakhtunkhwa (KPK) government's (Pakistan) support (GS) and entrepreneur knowledge (EK) on the development of small-medium-sized forest enterprises (SD) and their contribution to the local economic development (LED) of the region. Primary data were collected from 350 SMFEs in KPK, Pakistan. The model was developed by using a structural equation model (SEM) to investigate the impact of GS, EK, and SMFEs on the growth, SG, and sustainable development of the local economy. This study concludes that EK and GS could increase growth in SMFE businesses and contribute to LED. On the other hand, crediting loans and equipping businesses with training could not directly affect SMFE businesses and LED growth. The government needs to use natural resources and the SMFE communities as leaders among suppliers in the local market for the sustainable development of LED and SMFEs, alongside focusing on preserving and taking initiatives to develop. This study discusses several practical implications for policymakers, business owners, and academics, with recommendations for future research.
\end{abstract}

Keywords: SMEF development; local economic development; government support; entrepreneur knowledge; KPK; Pakistan

\section{Introduction}

Over recent decades, researchers, economists, policymakers, and entrepreneurs have agreed that SMFEs are an instrument of economic growth and poverty reduction $[1,2]$. The SMFE sector plays a crucial role in local economic development as a major source of livelihoods in the rural and less developed regions of a country [3,4]. They contribute to a country's business growth through job creation, developing entrepreneurship skills, generating high production volumes, increasing country exports, and generating income within rural poor and less developed regions in developing countries [5-7]. The active role of SMFEs in emerging economies ensures SMFEs act as engines through which economic growth, poverty reduction, and alleviation objectives of the Millennium Development Goals (MDG) can be achieved. SMFEs have gained much attention among the international agencies and government institutions in emerging economies. The government in one 
developing country initiated a developmental plan to support and promote the sustainable growth of SMFEs and achieve their objectives [8-10]. SMFEs can increase their productivity through government support. However, for SMFEs operating in a developing country at a different level, especially in rural and less developed regions, the enterprises cannot contribute to a country's exports directly through trading at a domestic level and conducting business with a country's large organizations, though this way, they contribute to LED. In developing countries, despite the government's and private sector's developmental plans to implement, support, and promote, SMFEs have been able to continue for a couple of decades. Furthermore, SMFEs meet many challenges that impose on their growth and, thus, their contribution towards LED [11-13].

However, SMFEs have always gained acceptance in the updated developmental literature because of their essential role in creating employment opportunities, poverty reduction, improving livelihoods, and LED $[14,15]$. SMFEs are the indispensable LED segment and solve socio-economic problems in many developing economies around the globe [6,16-18]. The literature shows that SMFEs are vital to a region's economic development and establishment because of their nature, as they are easy and primary sources of direct livelihood, employment, income, and innovation [10,19-21]. In developed countries such as Japan and those in Western Europe, the SME sector is the LED center [10,13,17].

The current study was confined to the development and growth of LED and SMFEs. Hence, the research was limited to the development of local economic development forest enterprises. Small-to-medium-sized forest enterprises (SMFEs) refer to small-to-medium enterprises (SMEs) located within the forest sector [3,22]. All SMFEs rely on forest-related activities as their principal source of revenue. Nonetheless, these activities are nearly endless, ranging from providing ecosystem services and yielding timber and non-timber forest product (NTFP) production to processing various commodities and value-added forest produce. As per the World Bank's statistics (Group [23]), more than $90 \%$ of the world's population with a low income depends on SMFEs for eking out their livelihood [23-25]. Such enterprises have a pivotal role in their inextricable association with forest-dependent communities. Their ostensible contribution goes beyond the generation of wealth to the diverse scopes of rural development [26-28].

SMFEs can help create jobs and produce revenue in developing countries. As Badini et al. [1] remarked, SMFEs account for 80-90\% of forest-related firms in developing countries and more than $50 \%$ of employment in tropical nations related to forestry [29], and at least 30 million people worldwide are directly employed by SMFEs [3]. These firms are mainly formed and developed in rural areas to establish and accelerate economic recovery and foster economic activity throughout regions by involving the general public in promoting social welfare and LED progress in these places.

More often than not, the development and the growth of SMFEs receive government support programs and entrepreneur knowledge. Government support programs for SMFEs are focused on local community dynamic changes. Government support includes assessing business legal documents, easy contact, positive policy implementation, access to technical support, raw material, media and communications, capacity building training, research, and business development. In contrast, entrepreneur knowledge includes managerial skills, communication, presentation, atypical skills, leadership vision, knowledge about functional disciplines, teamwork and building relationships, knowledge about protection of industrial and intellectual property, knowledge about logistics, quality assurance, marketing, strategic management, customer relations, operations, and preparing and implementing company plans. Enterprises are very successful and effective in solving enterprise problems, being willing to face new challenges. The relationship between the support initiatives by the government and entrepreneur knowledge across the development process and the success of businesses is significant. The government's assistance and entrepreneur knowledge programs should be accompanied by various policies that encourage business units' growth The enlargement of the business unit structure attempts to upgrade SMFEs by making them more broad or enormous and self-sufficient. The expansion of business units is defined by 
increasing the number of business units, investment amount, sales value, output, workforce strength, and proportion of export-quality production.

In 2017-2019, KPK had about 13,000 SMFE business units under the BTAP program, with more than 100,000 workers. Concerning the number of business entities, incorporating the workforce in the sectors mentioned above remained comparatively small. Still, the development impact on LED remained remarkably strategic to improve performance and to strengthen the growth of the current business entities, particularly in rural settings. Henceforth, the current study aims at collecting empirical evidence and analyzing the government's support in developing entrepreneur knowledge for SMFEs and its effects on the growing structure of the businesses and contribution to the local economic development in KPK, Pakistan.

Finally, this study examines the relationships between government support, entrepreneurship knowledge, and local economic development effectiveness. This may help better understand the relationships between government assistance and entrepreneur knowledge programs that encourage business growth and local economic development. Second, employee SMFE growth is critical in mediating the connection between government assistance, entrepreneur knowledge, and local economic development. This paper is organized as follows: Section 2 explains the theoretical framework and development of the hypothesis. Section 3 describes the materials and methods of the study. Section 4 discusses the study results. Section 5 presents the discussion. Section 6 presents the main conclusion implications and provides recommendations for future research.

\section{Theoretical Framework and Development of Hypothesis}

\subsection{Government Support and Local Economic Development}

The present research shows that a government can be positively significant in SMFE outcomes, e.g., regional economic development [30]. Open communication between the teams and other sector-wide support teams increases team members' ability to freely discuss ideas, draw on analytical insight, and empower followers to be self-directed and take on more leadership responsibilities [31]. Collaboration and high-level team communication create an atmosphere where team members remain committed to the local economy and help out with minor local projects $[32,33]$. The government empowers their subordinates by delegating power, making it worthwhile to pursue their ideas, and providing financial backing to investors to spur economic growth $[30,31,34]$. Setting goals in participatory manners and devolution of authority have proved to boost the performance of subordinates [35]. Problem solving in collaborative manners is vital for meeting particular targets by using action-oriented decision making to solve problems [31,36]. In addition, information that comes through the feedback loop, a primary facet of leadership, is critical in overcoming deficiencies within the sector, which boosts efficiency and helps reach the organization's purpose and objective $[31,37,38]$.

In addition, according to Tomaselli et al. [32], the government is a resource provider that encourages businesses to grow by fostering a specific resource phenomenon known as resource conservation [39]. That has proven critical in the development of organizational psychology in recent years. The resource model's basic principle of conservation is that individuals should endeavour to generate, conserve, maintain, and keep resources. The term "resources" refers to the goods, conditions, attributes, or energies that people value [40]. Moreover, the loss of such resources is far more harmful to an individual [40]. Additionally, the model shows that individuals with a reliable resource pool are the most "resource-secure" and in a position to grow their resource reservoir [40,41]. We believe that support is a critical personal resource for a government leader dedicated to building trust among followers, enabling them to foster an atmosphere of cooperation and coordination that results in the success of SMFEs and local economic development (i.e., resource gain).

The previous arguments suggest that the support of a government may increase team performance, ultimately leading to local economic development. That is why the following is proposed: 
Hypothesis 1. Government support has a positive relationship with local economic development.

\subsection{Entrepreneur Knowledge and Local Economic Development}

Entrepreneurship knowledge refers to creative people with great ideas, experience, knowledge, information, and innovative skills becoming engaged in entrepreneurial activities such as creating and using new ideas and expertise to develop the community and organization [42]. According to the resource-based view (RBV), an enterprise's competitive advantage and success depend on its tangible and intangible resources [43]. To sustain a viable lead, enterprises must be resourceful with an extensive knowledge base [44,45]. Hambrick and Mason [46] exposed the positive impact of knowledge on business sustainable development. According to a knowledge base view (KBV), knowledge is a resource that decides the business's sustainable growth and development. Hence, EK plays a vital role in local economic development $[47,48]$. EK contributes to the firm's knowledge base, helping to acquire changes in the corporate environment and take advantage of the space offered by these changes [49,50].

Thus, the enterprise should understand EK's value and operational function to improve the company information ability. EK has often been shown to be most important for firm growth [51,52]. Multiple research studies considered EK a vital organizational process that generally improves firms (Schallenkamp $[53,54]$ ). As EK encourages the renewal of current methods and searches for new opportunities for sustainable growth and development in businesses [55], prior EK performance research from both developing and developed countries indicates that EK is incredibly helpful for achieving business growth $[46,51,56]$. EK is an essential intangible resource of any firm to acquire and produce other resources to improve productivity and sustainable growth. Our hypothesis is based on the theoretical and empirical background that EK positively influences LED. Therefore, we hypothesize the following:

Hypothesis 2. Entrepreneur knowledge is significantly positive in terms of its effect on local economic development.

\subsection{Mediating Role of SMFE Development between GS and LED}

SMFEs serve as an engine to boost the local economy of rural settings by using resources in terms of forests and generating employment opportunities and local economic growth in the rural population [30,31,34]. Over recent decades, researchers, economists, policymakers, and entrepreneurs have agreed that SMFEs are the instrument of economic growth and poverty reduction. The SMFE sector plays a key role in local economic development (LED) and is a significant source of livelihoods in a country's rural and less developed regions. They contribute to a country's economic growth through job creation, developing entrepreneurship skills, generating high production volumes, increasing country exports, and generating income within rural poor and less developed regions in developing countries [5-7].

Local and national governments are critical in fostering a favorable business climate through appropriate regulation that fosters investment, employment, and economic development [57]. Governments can provide firms with legal and secure access to forest resources in the forest sector by enacting clear land tenure rules. They have the potential to streamline bureaucratic processes and thereby increase compliance with the law [58-60] and help decrease the flexible decisions taken by foresting communities and authorities [60]. Additionally, they can promote sector formality, which is often required for firms to obtain financing from financial institutions, enforce contracts and property rights, and be legally protected by the state $[61,62]$. It is not difficult for governments to curb illegal harvesting and overexploitation, thus mitigating biased competitions [58]. Finally, governments may apply proper regulations and taxation for all types of forest-based business entities, thereby impeding the process of prioritizing large-scale business firms seen across various segments of the globe [63]. As political and legislative reforms in the forest sector 
are complicated, creating an enabling environment for SMFEs needs several actors and government departments [64].

Governments worldwide may impede or promote the growth and development of SMFEs through adopting various regulations and policies. For instance, SMFEs in El Peten, Guatemala, benefited from constructing a transparent political framework that ensured their secure access to forest resources through the establishment of 25-year concessions [65]. China's government has aided forest firms by developing advantageous laws, such as a tenure reform that has transferred forest lands to households, fostering long-term sustainable forest management comparison. Forest companies in Malawi have been harmed due to a range of reasons including extensive government bureaucracy, official public corruption during product transit, and insecure access to resources [66]. Legally, the government's role stands as fundamental, having impacts, as Macqueen and Team [67] established that the business environment in various perspectives is regularly "piled against SMFEs".

The government can psychologically empower investors, providing the best investment opportunity in the SME sector [68,69]. For instance, modest government support recognizes the manager's/investor's contribution to economic growth, treats the investor with compassion, respect, and admiration, and instils in others the belief that their investment is profitable and impacts local economic development [70,71]. Humble government support also adds value to investors' ideas and suggestions, boosting investors' confidence and self-efficacy towards their investment, as well as their degree of expertise [72]. Additionally, the delegation of authority and openness to feedback demonstrated by government support liberate SMFE personnel from bureaucratic restraints and instil a sense of autonomy in them, allowing them to contribute to business goals [73]. The development of SMFEs is characterized by commitment and resilience, increasing efforts toward job creation, and local economic development [17], all of which are celebrated in practically every country. Due to their substantial contributions to the development and growth of many economies, they have been dubbed the growth engine and the vehicle for a country's socio-economic transformation. SMFEs are viewed as a legitimate means of achieving national economic objectives such as poverty reduction and job creation at a low investment cost. Another advantage of SMFEs is that they provide access to the infrastructural facilities made available by their very presence. Additionally, the stimulation of economic activities through the supply of manufactured goods and the distribution process from rural to urban areas improves the standard of living for employees and their families. They are connected to them both directly and indirectly [74]. The advantages of SMEs are numerous and cannot be overstated.

Regarding its economic contribution in terms of services and goods, employment generation entails opening jobs at lower costs. Such employment opportunities help decrease rural-to-urban migration, allowing even more utilization of resources available locally. This process helps to enhance the utilization of locally available raw materials and requires simple and non-complex technology for SMES in reducing income gaps by grouping both the semi-skilled and the skilled workforces for income growth. SMFEs provide significant opportunities for income production and economic activities in emerging nations' lowerincome and rural segments, particularly in agriculture, trading, and services. According to previous research, the creation of SMFEs acts as a stimulant for economic growth $[1,3,75,76]$. Increased SMFEs not only provide customers with a range of high-quality items at a low cost but they also provide a source of income, alleviate poverty, improve the society's welfare, and generate employment and economic development $[1,4,25,77]$. Similarly, SMFEs can contribute to local economic development and the national economy by doing this successfully.

The earlier discussion suggested that the development of SMFEs plays a mediating role between LED and the government's support. Moreover, the debate over the mediating role of SMFE development is founded on the resources proposed by the theory of resource conservation [78]. An approach for a positive gain of resources is employed in terms of the government's support to have a richer pool of resources capable of scoring more gains of 
resources for investors [78]. We believe that the government invests its resources in establishing a business network (e.g., the growth of SMFEs) that enables investors to allocate more resources to local economic development. As such, the growth of SMFEs appears to act as a buffer against the influence of government support on local economic development.

The mediating role is a covariance relation among the following variables: an assumed mediating variable, an independent variable, and a dependent variable [79]. The mediating variable (SMFE development) is examined to determine whether it accounts for a significant portion of the shared variance between the independent (government support) and dependent variables (LED) in the presence of the mediating variable, where the relationship between the independent and dependent variables changes. We suggest the following hypotheses based on the preceding discussion:

Hypothesis 3a. Government support is positively related to SMFE development.

Hypothesis 3b. SMFEs development is positively related to local economic development.

Hypothesis 3c. SMFEs developments mediate the relationship between government support and local economic development.

\subsection{The Mediating Role of SMFEs Development between EK and LED}

Entrepreneur knowledge has become part and parcel of SMFEs in times of the global competitive environment. Even though many entrepreneurs seldom consider the standing of entrepreneur knowledge, this can indeed be taken as a critical determinant of the development of SMFEs. The present study found that entrepreneur knowledge positively relates to SMFE development and local economic development [80]. Entrepreneurial expertise expands the opportunities for SMFEs, which contribute to the region's economic development [81]. By involving people in decision making, entrepreneurs foster a sense of self-confidence in their ability to perform well and encourage free contact with other stakeholders, resulting in the development, promotion, and implementation of new and valuable ideas [82]. According to Hobfoll [39], the COR theory suggests that to acquire resources, other resources must be utilized. EK is the primary resource of any enterprise, and through the proper utilization of EK, an enterprise can easily access other resourses for development.

Similarly, Eniola and Entebang [83] also pointed out that knowledge is strongly linked to SMFE development. The empirical literature has investigated that if a firm has EK, it can quickly accrue other resourses. Li, Zhao [84] also found a similar result: when an organization possesses EK, it can compete in the market and achieve organization goals. Li, Huang [85,86] provided evidence on EK. Hartsfield, Johansen [87] found that firms with high levels of EK can engage in identifying needs, strategic planning, efficiently fulfilling requirements, and identifying fresh development opportunities.

Previous research has indicated that SMFEs have immense importance for the economic development of any country [88-91]. SMEs account for about $95 \%$ of enterprises, $60-70 \%$ of employment, and a sizable portion of new jobs in OECD countries. Thus, SMEs are critical to a region's economic development, as they generate the majority of new jobs and innovations. Small and medium-sized enterprise (SME) development concerns industrial revival, job creation, export growth, and productivity. As a result, innovative economic development is expected to improve SMFE performance since SMFEs with innovative capabilities are better at predicting and detecting development possibilities and developing novel solutions to problems encountered in their work [3,92], thus making an organization capable of succeeding in a vibrant business environment [93]. Many research studies have shown that the relative development of an economy is due to the development and growth of SMFEs $[94,95]$. Thus, SMFE development acts as an intermediate variable that can mediate the relationship between entrepreneur knowledge and local economic development. Consequently, the following is hypothesized: 
Hypothesis 4a. Entrepreneur knowledge is positively linked with SMFEs development.

Hypothesis $4 \mathbf{b}$. SMFEs developments mediate the relationship between entrepreneur knowledge and LED.

\section{Materials and Methods}

\subsection{Data Collection and Selected Population}

The above hypotheses were tested through the data collected from SMEs operating in the forest sector in Khyber Pakhtunkhwa Province (KPK), Pakistan, in the area of the BTAP program. The targeted area for research was chosen because a large number of SMFEs are based in it. Due to the lack of a precise database of SMFEs in Pakistan, identifying sampling techniques for this study arose as a challenging task. Therefore, a list of registered business units from the BTAP was obtained. We asked the owners to take part in the survey because they are the accountable authorities and aware of the administrative operations of their business. This study followed a convenience sampling technique. The hard copy approach was opted for over an email survey because in a developing country such as Pakistan, the email approach would provide a lower response rate [96]. For this research, a structured questionnaire was employed to gather data since such methods effectively elicit information on the sample's attitudes, opinions, and values $[97,98]$. To facilitate data collection, eight enumerators were hired with lower survey experience of approximately five years with national-level organizations to cover different country cities. Fifty questionnaire copies were provided to each enumerator, and each enumerator was asked to hand out the questionnaires to owners/managers of various SMFEs operating in the field of study. The questionnaire was conducted in the English language, as that is the medium of instruction. The questionnaire specified that the data obtained would be used solely for research purposes and would not be made public.

Additionally, to encourage candid and accurate responses, the cover letter emphasized that participation was optional, private, and anonymous and that there were no true or false responses for specific items. The follow-up survey received a surprisingly high number of responses, with 363 questionnaires returned out of 400 distributed questionnaires, and 13 that were dropped due to careless responses. Three hundred and fifty were useful for analysis ( $87.5 \%$ response). The demographic described proposed that the age of $86 \%$ $(n=301)$ of the participants was $20-45$ years, where $98.3 \%(n=344)$ were male.

\subsection{Measures}

From previous research, the scales of the main variables were adjusted through modification as and where necessary to improve the compatibility for this research investigation. All of the items were measured on a five-point Likert scale in which $1=$ strongly disagree and $5=$ strongly agree.

\subsubsection{Government Support (GS)}

Due to the lack of availability of previous studies, it is difficult to measure the GS impact on SMFEs and LED. We measured GS by adapting some of the measurement scales from Abrar-ul-Haq, Jali [73] and modifying them for the current research.

\subsubsection{Entrepreneurship Knowledge (EK)}

The lack of availability of previous studies makes it difficult to measure the EK impact on SMFEs and LED. We measured EK by using the dimension of education level, knowledge about functional disciplines, self-confidence, and work experience. Some of the measurement scales were adapted from Gomezelj Omerzel and Antončič [45] and modified for the current study. 


\subsubsection{SMFEs Development (SD)}

Due to the absence of publicly accessible data on SMFEs, financial matters in emerging economies such as Pakistan make it challenging to measure the development of SMFEs. SMFE development was measured based on the sales and assets dimension used by Davidsson [99] and Delmar, Davidsson [100].

\subsubsection{Local Economic Development (LED)}

The lack of availability of previous studies makes it difficult to measure the GS, EK, and SMFE impact on LED. We measured LED by using the different aspects of economic development such as employment, poverty, and income generation. Some of the measurement scales were adapted from Hidayat and Akhmad [101] and Adam and Pettenella [77] and modified for the current research.

\subsubsection{Control Variable}

Gender, educational level, and job experience have been established to affect the success of SMFEs, and thus they have previously been incorporated as control variables [102] Hence, gender, experience, and education were considered as the control variables.

\subsection{Confirmatory Factor Analysis}

Confirmatory factor analysis (CFA) was conducted to see whether the hypothesized four-factor model fits the data well. The CFA results show an excellent model fit with $\chi^{2}=(1587.88), \mathrm{df}=(971), \chi^{2} / \mathrm{df}=(1.635), \mathrm{TLI}=(0.947), \mathrm{CFI}=(0.951)$, and RMSEA $=(0.043)$, in accordance with the standards. Therefore, the study data fit our proposed hypothesized model well. Next, the four latent variables were evaluated for composite reliability (CR), convergent validity, and discriminant validity. The $C R$ values for all the constructs were greater than 0.9 , showing excellent internal consistency $[103,104]$. Convergent validity was verified by using the values of the average variance extracted (AVE). AVE values should be greater than 0.5 to achieve convergent validity among the study hypotheses [105]. The AVE values for all the constructs were greater than 0.5 , verifying that there is no issue of convergent validity among these constructs. Discriminant validity was tested following the Fornell-Larcker approach [103]. The criterion was fulfilled because the square root of the AVE value of all the constructs was greater than the correlation among all the constructs, as shown in Table 1.

Table 1. Mean, standard deviation, validity, and correlation matrix.

\begin{tabular}{ccccccccc}
\hline Variable & CR & AVE & M & SD & LED & GS & EK & SD \\
\hline LED & 0.95 & 0.67 & 2.5 & 0.89 & $(0.82)$ & & & \\
GS & 0.95 & 0.63 & 2.4 & 0.70 & $0.14^{* *}$ & $(0.79)$ & & \\
EK & 0.95 & 0.67 & 3.7 & 0.90 & $0.13^{*}$ & -0.02 & $(0.82)$ & \\
SD & 0.94 & 0.65 & 3.3 & 1.03 & $0.17^{* *}$ & $0.13^{*}$ & $0.14^{* *}$ & $(0.80)$ \\
\hline
\end{tabular}

Notes: The variances entered are diagonal; correlations are off-diagonal. ${ }^{*} p<0.05,{ }^{* *} p<0.01$ (two-tailed); AVE average variance extracted; SD, SMFE development; CR, composite reliability; EK, entrepreneurship knowledge; GS, government support; M, mean; SD, standard deviation; LED, local economic development.

\section{Results}

\subsection{Analysis Techniques and Validity of the Construct}

AMOS version 23 and SPSS were utilized for data analysis which was conducted in three different steps. Firstly, exploratory factor analysis (EFA) was executed to know whether the given factors loaded on their respective component or not. Secondly, confirmatory factor analysis (CFA) was conducted in order to examine the latent variables underlying the shared items [106]. Thirdly, the study's hypothesized paths were analyzed by using the structural equation modeling (SEM) technique. It is considered one of the most favored techniques in causal modeling because it provides a control for the measurement error and information about the model fit of the given model $[107,108]$. This study 
used the reflective constructs of government support, entrepreneur knowledge, SMFE development, and local economic development. These constructs were further tested for convergent validity, internal consistency, and discriminant validity. Composite reliability was used to check the internal consistency in the respective constructs. The outer loadings of the different variables' indicators show a combined reliability value greater than 0.94 . Convergent validity was established by using the average variance extracted (AVE) which shows acceptable values of 0.63 or greater (see Table 1). The normal construct elucidates that most of the variance of indicators is in accordance with [109]. The Fornell-Larcker approach was utilized for testing the discriminant validity of the study constructs [110]. The standard was met as the square root of the AVE values was greater than the highest correlation between the given constructs [110]. To further establish the construct validity, the indicators' outer loading values are higher than 0.94 , and the construct loadings on the indicators (see Table 1) are larger than all of the cross-loadings with other constructs, thus demonstrating discriminatory validity.

\subsection{Model Fit}

After confirming the reliability and validity of the constructs' research scales, in the next step, we checked the model fit. To investigate the structural model feasibility, we used model fit statistics such as $\chi^{2}$, the root mean square error of approximation (RMSEA), the comparative fit index (CFI), and the Tucker-Lewis index (TLI) [106]. According to the researchers, the model will be acceptable when $\chi^{2}$ is significant, the TLI and CFI values are higher than 0.9 , and the RMSEA value is equal to or less than 0.08 [106,111]. In this study, $\chi^{2}=(1587.88), \mathrm{df}=(971), \chi^{2} / \mathrm{df}=(1.635), \mathrm{TLI}=(0.947), \mathrm{CFI}=(0.951)$, and $\mathrm{RMSEA}=(0.043)$, which is in accordance with the standards. Therefore, the study data fit our proposed hypothesized model well.

\subsection{Direct Relationship}

First, we examined the direct relationship between the study variables of government support, entrepreneurship knowledge, SMFE development, and local economic development. As hypothesized by the researchers, we found a significant positive relationship for GS with LED $(\beta=0.13, p<0.05)$, and EK with LED $(\beta=0.16, p<0.01)$. This supports our study's proposed hypotheses $\mathrm{H} 1$ and $\mathrm{H} 2$ (see Figure 1). The direct relationships between GS and SD $(\beta=0.14, p<0.01)$ and EK and SD $(\beta=0.14, p<0.01)$ were also found to be positive and significant by proving our study hypotheses $\mathrm{H} 3 \mathrm{a}$ and $\mathrm{H} 4 \mathrm{a}$, which were also accepted (see Figure 1). Next, the relationship between SD and LED $(\beta=0.13, p<0.05)$ was found to be positive and significant; this supports hypothesis H3b. It was found that upkeep for the direct effect was part of the first step, and the test for the potential impact of mediation was part of the second step (see Figure 1 and Table 2).

\subsection{Indirect Relationship}

The proposed indirect relationship was analyzed by using the parametric bootstrap procedure [112]. What is prominent about bootstrap tests as that they start detecting once the mediated effect distribution of sampling is weighted away from 0 [113]. We calculated the parameter estimates' 95\% confidence intervals (CIs) using 5000 data samples from data from 350 responses. The upper and lower bound results exclude 0 for SD between GS and LED and EK and LED, which show that SD functions as a mediator according to conventional standards. The result of the bootstrap shows a positive mediating role of SD between SG and LED (estimate $=0.029 *, \mathrm{SE}=0.014,95 \%$ CI $[0.007,0.069]$ ). Likewise, the relationship between EK and LED was also positively and significantly mediated by SD (estimate $=0.024 *$, SE $0.012,95 \%$ CI $[0.006,0.057])$; therefore, H3c and H4b were supported (Table 3). 


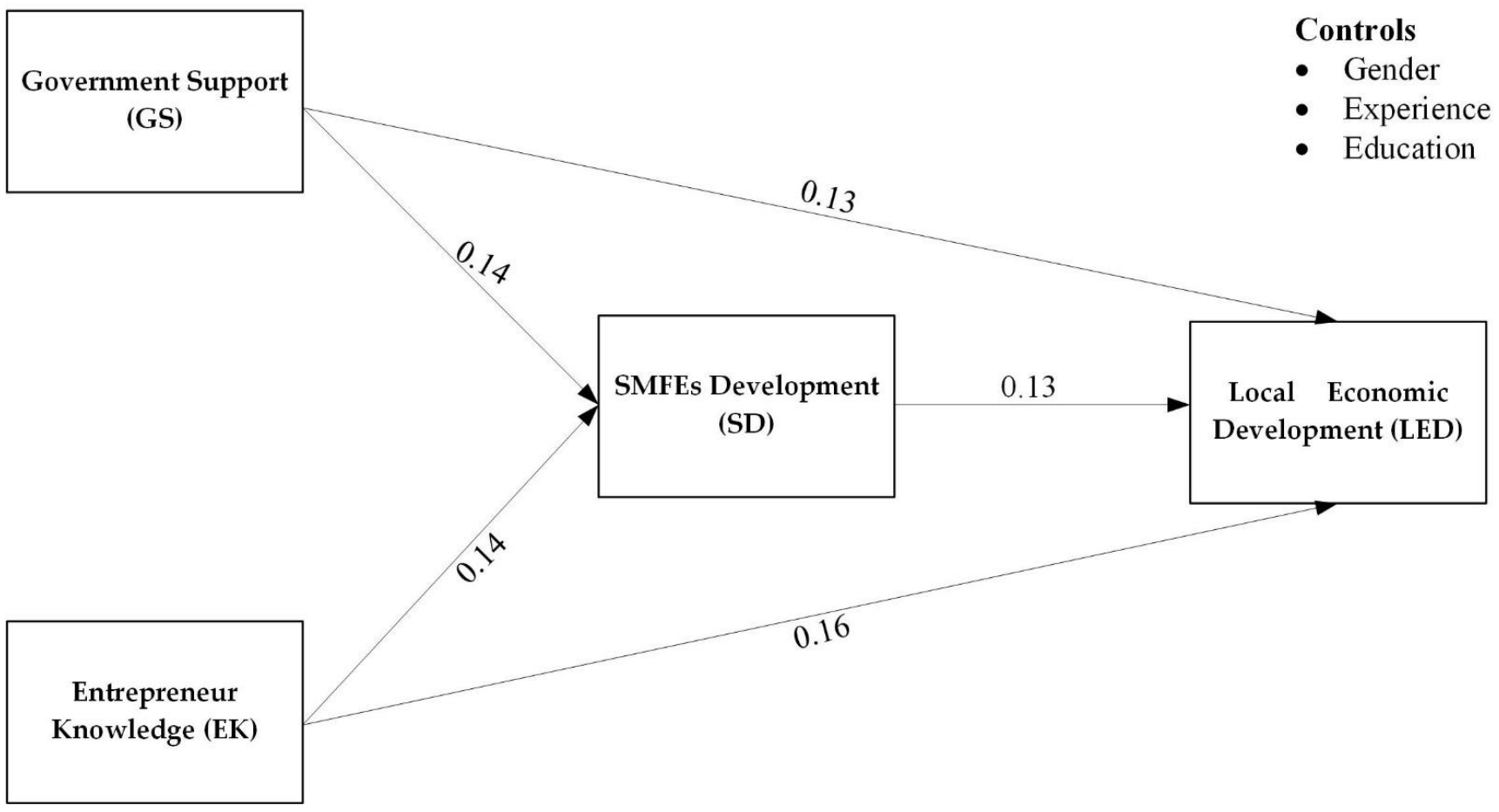

Figure 1. Study model.

Table 2. Structural equation model path analysis results.

\begin{tabular}{llccc}
\hline \multicolumn{1}{c}{ Path } & & Coefficient & SE & $t$-Value \\
\hline \multicolumn{1}{c}{ Control } & & & & \\
Local economic development & $\leftarrow$ Gender & -0.02 & 0.15 & -0.03 \\
SMFE development & $\leftarrow$ Gender & 0.01 & 0.18 & 0.18 \\
Local economic development & $\leftarrow$ Experience & -0.14 & 0.14 & 1.62 \\
SMFE development & $\leftarrow$ Experience & 0.08 & 0.16 & 2.21 \\
Local economic development & $\leftarrow$ Education & $0.12^{*}$ & 0.08 & 1.03 \\
SMFE development & $\leftarrow$ Education & 0.10 & 0.10 & 0.36 \\
& & & & \\
Local economic development & $\leftarrow$ Govt Support & $0.14^{*}$ & 0.08 & 2.54 \\
Local economic development & $\leftarrow$ Entrepr Kn & $0.16^{* *}$ & 0.06 & 2.82 \\
SMFE development & $\leftarrow$ Govt Support & $0.14^{*}$ & 0.07 & 2.47 \\
SMFE development & $\leftarrow$ Entrepr Know & $0.13^{*}$ & 0.05 & 2.34 \\
Local economic development & $\leftarrow$ SMFE Development & $0.13^{*}$ & 0.04 & 2.24 \\
\hline Notes $*^{*} p<0.05 * * *<0.01$ & & & &
\end{tabular}

Notes $={ }^{*} p<0.05 ;{ }^{* *} p<0.01$.

Table 3. Mediating effect of access to finance.

\begin{tabular}{cccccc}
\hline \multirow{2}{*}{ Variable } & \multirow{2}{*}{$\begin{array}{c}\text { Standardized } \\
\text { Indirect Effects }(\beta)\end{array}$} & $S E$ & \multicolumn{2}{c}{$\begin{array}{c}\mathbf{9 5 \%} \text { Biased-Corrected } \\
\text { Confidence Interval }\end{array}$} & $\mathbf{R}^{\mathbf{2}}$ \\
\cline { 4 - 6 } & & & Lower Bounds & Upper Bounds \\
\hline $\mathrm{GS} \rightarrow \mathrm{SD} \rightarrow \mathrm{ED}$ & $0.029^{*}$ & 0.014 & 0.007 & 0.069 & 0.019 \\
\hline $\mathrm{EK} \rightarrow \mathrm{SD} \rightarrow \mathrm{LED}$ & $0.024^{*}$ & 0.012 & 0.006 & 0.057 & 0.019
\end{tabular}

Note: GS = government support (independent variable). EK = entrepreneurship knowledge (independent variable). $\mathrm{SD}=\mathrm{SMFE}$ development (mediator). $\mathrm{LED}=$ local economic development (dependent variable) $\mathrm{SE}=$ bootstrap standard error. Number of bootstrap samples $=5000 .{ }^{*} p<0.01$.

\section{Discussion}

This study's main objective was to investigate GS's and EK's role in local economic development using a structural equation model. The direct and indirect (via SMFE development) influences of GS and EK on local economic development were analyzed. Additionally, 
in the current study, we attempted to quantify the direct impact of SMFE development on local economic development. Following a rigorous examination of the literature, we built a conceptual framework and seven hypotheses to serve as the foundation for our analysis. The findings show that GS and EK have a positive effect on local economic development and SMFE development. Moreover, SMFE development (SD) was recognized as a mediator of the relationship between GS, EK, and LED and positively affected local economic development.

The direct and positive effect of the government's support on the growth of SMFEs is in line with the studies of Smallbone and Welter [30], who also found a positive and direct effect on SMFE development.

GS and EK are recognized as critical factors in the intellectual capital of enterprises. Therefore, our findings remain consistent with those of Carmeli and Tishler [114], which found a positive effect of intellectual capital on the development of SMEFs and economic development. Moreover, GS contributes to the expansion of SMFEs by ensuring that they are prepared to deal with unanticipated economic shocks and a rapidly changing financial and credit market [115]. Similar results were found by Tomaselli, Timko [31], who found that GS enables firms to identify profitable business and investment opportunities.

The influence of entrepreneur knowledge on local economic development (EK) has not been receiving enough attention. EK influences LED indirectly (via SD). Due to the different vital levels of EK such as education, knowledge, experience, skills, and vision, which are the primary functional disciplines through which a business entity can achieve a competitive benefit, these are the critical elements for the local development of SMFEs and regional economics. It was found that firm growth and development depend on the entrepreneur's confidence level. Our study findings are inconsistent with those of Boeker [116], who found that experience, skills, and formal education are vital for the development of businesses and economic growth, and similar results were found by Hambrick and Mason [46], who noted that highly qualified managers/owners appear to be more comfortable with new ideas, bringing about growth and development in the firm [46]. Knowledge is considered an integral part of human capital and the most critical factor in selecting and managing crucial resources to implement the desired strategy for achieving sustainable business development $[117,118]$. However, this is the first study to measure the direct and indirect effects (via SD) of EK on the growth of LED. This is the main contribution to the literature of entrepreneurship and small business management worldwide.

The results of this study show a significant correlation among SD and SME sustainable growth, consistent with Okello Candiya Bongomin et al.. [119], and Storey [120], who reported the efficiency of financial access which positively influenced SMFEs' performance. In the study of Ahlstrom, Cumming [121], the authors found it more challenging for SMFEs than large firms, which may reduce SMFE sustainability. Furthermore, according to [122], SD also has an impact on innovation and economic growth. In general, the evidence indicates that SMFEs with a more robust development capacity are better positioned to maintain their growth and survive in the competitive environment of today's markets. SMFEs in emerging economies have difficulty accessing adequate competitive financial services for growth and development [123].

As a camper to large businesses, SMFEs are generally distinguished by a shortage of entrepreneur knowledge and GS. Due to this vulnerability, they have limited access to external financial resources. Our results show that GS had a significant effect on SMFEs development SD, which is congruent with the study of Wise [124] that found government financial support was a significant determinant of SMFE development. In addition, our results are consistent with those of [31], who stated that GS was favorably related to the sensitivity of various SDs and the ability to recognize suitable sources of business finance. This shows that SMFEs need GS to close the "equity gap", that is, as compared to small businesses, the larger businesses pay the higher interest because this provides a more favorable chance of taking a loan. Proper GS in training and development would also encourage SMFEs to prepare and maintain timely, accurate, and relevant business 
financial reports and statements needed for business development access to finance and therefore assist in solving the problem of funds scarcity [125] of SMFEs in emerging economic markets.

The influence of entrepreneur knowledge on SMFEs development has not received adequate consideration. Therefore, we attempted to fill this research gap by examining the effect of EK on SMFEs. We found that EK positively affects SMFE development, consistent with Gomezelj Omerzel and Antončič [45], indicating that a more significant education rate reduces the inherent risks associated with commercial activity. While Gomezelj Omerzel and Antončič [45] did not distinguish between education and EK, their findings are similar to ours since EK and education aim to limit avoidance by ensuring that employees have the necessary skills to make rational company management decisions. As they are more willing to take risks, better educated SMFEs are considerably more likely to gain extremely successful investment possibilities. We found that SMFE development mediated the relationship between GS, EK, and local economic development. The notion that SD mediates the relationship between GS and local economic development is consistent with COR theory, which suggests that GS and EK improve the growth of SMFEs by reducing the knowledge gap and contribute to economic development. GS and training make SMFEs capable of generating a strong and effective corporate capital structure, thereby reducing their capital expenditures and improving their profitability. Our results are in line with those of Doh and Kim [34], who argued that GS and EK are vital to making smart investments and business decisions and improving the sustainability of SMFEs and economic growth. GS and EK impact spatial cognition, strengthening organizational capacity for learning, estimating, problem solving, and decision making [126], leading to the best decision making and strengthening business sustainability in the market. Therefore, it should be recognized that GS and EK are vital to SMFE and local economic development, and they are directly linked to SMFE sustainable development and have an indirect effect through associations with SMFE development. Thus, our investigation of the relationships between local economic development and its GS, EK, and SMFE development extends the knowledge of GS and EK by the identification of new paths which can improve SMFEs' sustainable growth and local economic development.

\section{Conclusions}

This study was undertaken to check the indirect effect of entrepreneur knowledge, government support, and SMFE development on local economic development. Moreover, the mediating effect of SMFE development in the relationship between government support, entrepreneur knowledge, and local economic development was examined. It is clear that significant government support and entrepreneur knowledge help develop SMFEs and contribute to the region's local economic development.

This study's findings show the positive and direct effect of GS on the growth of SMFEs and the positive impact of GS on local economic development. SMFE development positively mediates the relationship between government support and local economic development. Similar results were found for entrepreneur knowledge on SMFE development and local economic development. SMFE development mediates the relationship between entrepreneur knowledge and local economic development.

This paper credits both theoretical and practical implications for academics and the government. Firstly, by discussing the concept of government support, entrepreneur knowledge, and SMFEs from a local economic development perspective, this paper creates a notion that these theories are harmonious. Secondly, by sampling how these concepts support SMFE growth and contribute to regional economic development, this paper provides the Pakistani government with hands-on investor advice to legally engage with the existing SMFEs to perform its rural development programs. Finally, while SMFEs and their LED role in empowering a disadvantaged community were comprehensively investigated, real evidence is documented that can best challenge its radicalism, terrorism, and poverty issues. Based on the above discussion and analysis, this study has a few limitations. Future 
research can fill this void, as described further. Firstly, it is anticipated to extend the study to the entire KPK Province. Scaling up the research across Pakistan would encounter the economic, cultural, and social patterns anticipated to evolve different behaviors. Secondly, the data are cross-sectional. Therefore, future investigators should conduct longitudinal research in other provinces of Pakistan. The same research might be very effective in other countries' cultural contexts.

Author Contributions: Conceptualization, M.Z., S.Z. and Y.Z.; methodology, M.A. and A.B.; writing, M.A., H.H., A.A.-M. and A.V.-M.; supervision, S.Z., H.H., A.A.-M. and A.V.-M.; project administration; H.H., A.A.-M. and A.V.-M.; funding acquisition, H.H., A.A.-M. and A.V.-M. All authors have read and agreed to the published version of the manuscript.

Funding: This research received no external funding.

Institutional Review Board Statement: Not applicable.

Informed Consent Statement: Not applicable.

Data Availability Statement: The data presented in this study are available on request. The data are not publicly available due to privacy reasons.

Conflicts of Interest: The authors declare that there is no conflict of interest.

\section{References}

1. Badini, O.S.; Hajjar, R.; Kozak, R. Critical success factors for small and medium forest enterprises: A review. For. Policy Econ. 2018, 94, 35-45. [CrossRef]

2. Zada, M.; Yukun, C.; Zada, S. Effect of financial management practices on the development of small-to-medium size forest enterprises: Insight from Pakistan. GeoJournal 2021, 86, 1073-1088. [CrossRef]

3. Kozak, R. Small and Medium Forest Enterprises: Instruments of Change in the Developing World. Small E Medium Forest Enterprises in Mozambique; Rights and Resources Initiative: Washington, DC, USA, 2007.

4. Zada, M.; Shah, S.J.; Yukun, C.; Rauf, T.; Khan, N.; Shah, S.A.A. Impact of Small-to-Medium Size Forest Enterprises on Rural Livelihood: Evidence from Khyber-Pakhtunkhwa, Pakistan. Sustainability 2019, 11, 2989. [CrossRef]

5. Khalique, M.; Bontis, N.; Bin Shaari, J.A.N.; Isa, A.H.M. Intellectual capital in small and medium enterprises in Pakistan. J. Intellect. Cap. 2015, 16, 224-238. [CrossRef]

6. Rasheed, R.; Siddiqui, S.H.; Mahmood, I.; Khan, S.N. Financial Inclusion for SMEs: Role of Digital Micro-financial Services. Rev. Econ. Dev. Stud. 2019, 5, 563-572. [CrossRef]

7. Tadesse, E. The Role of Micro and Small Enterprises on Local Economic Development: The Case of Nifas Silk Lafto Sub-City. Ph.D. Thesis, St. Mary's University, Twickenham, UK, 2016.

8. Chemin, M. Entrepreneurship in Pakistan: Government policy on SMEs, environment for entrepreneurship, internationalisation of entrepreneurs and SMEs. Int. J. Bus. Glob. 2010, 5, 238-247. [CrossRef]

9. Mmakola, D. South Africa's SMME policy-the challenge remains. Africanus 2009, 39, 66-81.

10. Ihua, U.B. SMEs key failure-factors: A comparison between the United Kingdom and Nigeria. J. Soc. Sci. 2009, 18, 199-207. [CrossRef]

11. Bai, Y.; Yuan, J.; Pan, J. Why SMEs in emerging economies are reluctant to provide employee training: Evidence from China. Int. Small Bus. J. 2017, 35, 751-766. [CrossRef]

12. Tahir, F.A.; Inuwa, F.U. Empirical Investigation of the Factors Affecting Micro, Small and Medium Scale Enterprises Performance in Borno State, Nigeria. Int. Bus. Res. 2019, 12, 30-39. [CrossRef]

13. Chew, R.; Chew, S.-B. A study of SMEs in Singapore. J. Enterprising Communities People Places Glob. Econ. 2008, 2, 332-347. [CrossRef]

14. Abisuga-Oyekunle, O.A.; Fillis, I.R. The role of handicraft micro-enterprises as a catalyst for youth employment. Creat. Ind. J. 2017, 10, 59-74. [CrossRef]

15. Delbiso, T.D.; Deresse, F.N.; Tadesse, A.A.; Kidane, B.B.; Calfat, G.G. Informal sector and urban unemployment: Small businesses contribution to large livelihood improvements. Int. J. Entrep. Small Bus. 2018, 34, 169-182. [CrossRef]

16. Chandrarin, G.; Sanusi, A.; Imron, A.; Yuniarti, S. An empirical study on income equality, economic growth and financial inclusion in Indonesia: Model development on SMEs financing. Int. J. Educ. Econ. Dev. 2018, 9, 346-365. [CrossRef]

17. Kongolo, M. Job creation versus job shedding and the role of SMEs in economic development. Afr. J. Bus. Manag. 2010, 4, 2288-2295.

18. Lerario, A.; Di Turi, S. Sustainable urban tourism: Reflections on the need for building-related indicators. Sustainability 2018, 10, 1981. [CrossRef]

19. Chege, S.M.; Wang, D. Information technology innovation and its impact on job creation by SMEs in developing countries: An analysis of the literature review. Technol. Anal. Strateg. Manag. 2019, 32, 256-271. [CrossRef] 
20. Raymond, C.; Gulsrud, N.; Rodela, R.; Randrup, T.; Hegelund, S. Rethinking Urban Nature to Promote Human Well-Being and Livelihoods. 2018. Available online: https://www.researchgate.net/publication/322941071_Rethinking_urban_nature_to_ promote_human_well-being_and_livelihoods (accessed on 12 May 2020).

21. Rasheed, R.; Yasar, A.; Tabinda, A.B.; Khan, N.; Su, Y.; Afzaal, M. Techno-Economic Impacts of Innovative Commercialindustrial Scale Bioenergy Plant in Pakistan. Pak. J. Agric. Sci. 2016, 53, 647-652. [CrossRef]

22. Ayyagari, M.; Demirgüç-Kunt, A.; Beck, T. Small and Medium Enterprises Across the Globe: A Neww Database; The World Bank Publications: Washington, DC, USA, 2003.

23. Group, W.B. A Revised Forest Strategy for the World Bank Group; World Bank Publications: Washington, DC, USA, 2002.

24. Appiah, M.; Blay, D.; Damnyag, L.; Dwomoh, F.K.; Pappinen, A.; Luukkanen, O. Dependence on forest resources and tropical deforestation in Ghana. Environ. Dev. Sustain. 2009, 11, 471-487. [CrossRef]

25. Chao, S. Forest Peoples: Numbers Across the World; Forest Peoples Programme: Moreton-in-Marsh, UK, 2012.

26. Rauf, T.; Khan, N.; Shah, S.J.; Zada, M.; Malik, S.Y.; Yukun, C.; Sadique, A. Poverty and Prosperity: Impact on Livelihood Assets of Billion Trees Afforestation Program in Khyber Pakhtunkhwa (KPK), Pakistan. Forests 2019, 10, 916. [CrossRef]

27. Khan, N.; Shah, S.J.; Rauf, T.; Zada, M.; Yukun, C.; Harbi, J. Socioeconomic impacts of the billion trees afforestation program in Khyber Pakhtunkhwa Province (kpk), Pakistan. Forests 2019, 10, 703. [CrossRef]

28. Baker, M.; Kusel, J. Community Forestry in the United States: Learning from the Past, Crafting the Future; Island Press: Washington, DC, USA, 2003.

29. Mayers, J. Small and medium-sized forestry enterprises. ITTO Trop. For. Update 2006, 16, 10-11.

30. Smallbone, D.; Welter, F. The role of government in SME development in transition economies. Int. Small Bus. J. 2001, 19, 63-77. [CrossRef]

31. Tomaselli, M.F.; Timko, J.; Kozak, R. The role of government in the development of small and medium forest enterprises: Case studies from The Gambia. Small-Scale For. 2012, 11, 237-253. [CrossRef]

32. Maqbool, R.; Sudong, Y. Critical success factors for renewable energy projects; empirical evidence from Pakistan. J. Clean. Prod. 2018, 195, 991-1002. [CrossRef]

33. Yang, L.-R.; Huang, C.-F.; Wu, K.-S. The association among project manager's leadership style, teamwork and project success. Int. J. Proj. Manag. 2011, 29, 258-267. [CrossRef]

34. Doh, S.; Kim, B. Government support for SME innovations in the regional industries: The case of government financial support program in South Korea. Res. Policy 2014, 43, 1557-1569. [CrossRef]

35. Ahearne, M.; Mathieu, J.; Rapp, A. To empower or not to empower your sales force? An empirical examination of the influence of leadership empowerment behavior on customer satisfaction and performance. J. Appl. Psychol. 2005, 90, 945. [CrossRef]

36. Sohmen, V.S. Leadership and teamwork: Two sides of the same coin. J. IT Econ. Dev. 2013, 4, 1-18.

37. Qian, J.; Song, B.; Jin, Z.; Wang, B.; Chen, H. Linking empowering leadership to task performance, taking charge, and voice: The mediating role of feedback-seeking. Front. Psychol. 2018, 9, 2025. [CrossRef]

38. Ali, M.; Li, Z.; Zhenduo, Z.; Zada, M.; Begum, A.; Han, H.; Montes, A.A.; Muñoz, A.V. Can Leader Humility Enhance Project Management Effectiveness? Interactive Effect of Top Management Support. Sustainability 2021, 13, 9526. [CrossRef]

39. Hobfoll, S.E. Conservation of resources: A new attempt at conceptualizing stress. Am. Psychol. 1989, 44, 513. [CrossRef] [PubMed]

40. Hobfoll, S.E. The influence of culture, community, and the nested-self in the stress process: Advancing conservation of resources theory. Appl. Psychol. 2001, 50, 337-421. [CrossRef]

41. Hobfoll, S.E.; Johnson, R.J.; Ennis, N.; Jackson, A.P. Resource loss, resource gain, and emotional outcomes among inner city women. J. Personal. Soc. Psychol. 2003, 84, 632. [CrossRef]

42. Skrzeszewski, S. Knowledge Entrepreneur; Scarecrow Press: Lanham, MD, USA, 2006.

43. Das, T.K.; Teng, B.-S. A resource-based theory of strategic alliances. J. Manag. 2000, 26, 31-61. [CrossRef]

44. Conner, K.R.; Prahalad, C.K. A resource-based theory of the firm: Knowledge versus opportunism. Organ. Sci. 1996, 7, 477-501. [CrossRef]

45. Omerzel, D.G.; Antončič, B. Critical entrepreneur knowledge dimensions for the SME performance. Ind. Manag. Data Syst. 2008, 108, 1182-1199. [CrossRef]

46. Hambrick, D.C.; Mason, P.A. Upper echelons: The organization as a reflection of its top managers. Acad. Manag. Rev. 1984, 9, 193-206. [CrossRef]

47. Hsu, R.-C.; Lawson, D.; Liang, T.-P. Factors affecting knowledge management adoption of Taiwan small and medium-sized enterprises. Int. J. Manag. Enterp. Dev. 2007, 4, 30. [CrossRef]

48. Novak, M.; Bojnec, S. Human capital and economic growth by municipalities in Slovenia. Manag. Glob. Transit. $2005,3,157$.

49. Grant, P.; Perren, L. Small Business and Entrepreneurial Research Meta-theories, Paradigms and Prejudices. Int. Small Bus. J. 2002, 20, 185-211. [CrossRef]

50. Grant, R.M. Toward a knowledge-based theory of the firm. Strateg. Manag. J. 1996, 17, 109-122. [CrossRef]

51. Cowling, M.; Liu, W.; Ledger, A.; Zhang, N. What really happens to small and medium-sized enterprises in a global economic recession? UK evidence on sales and job dynamics. Int. Small Bus. J. 2015, 33, 488-513. [CrossRef]

52. Odorici, V.; Presutti, M. The entrepreneurial experience and strategic orientation of high-tech born global start-ups: An analysis of novice and habitual entrepreneurs. J. Int. Entrep. 2013, 11, 268-291. [CrossRef] 
53. Smith, W.L.; Schallenkamp, K.; Eichholz, D.E. Entrepreneurial skills assessment: An exploratory study. Int. J. Manag. Enterp. Dev. 2006, 4, 179-201. [CrossRef]

54. Schallenkamp, K.; Smith, W.L. Entrepreneurial skills assessment: The perspective of SBDC directors. Int. J. Manag. Enterp. Dev. 2008, 5, 18-29. [CrossRef]

55. Lassen, A.H. Corporate entrepreneurship: An empirical study of the importance of strategic considerations in the creation of radical innovation. Manag. Glob. Transit. 2007, 5, 109.

56. Javalgi, R.R.G.; Todd, P.R. Entrepreneurial orientation, management commitment, and human capital: The internationalization of SMEs in India. J. Bus. Res. 2011, 64, 1004-1010. [CrossRef]

57. IFC. Simplification of Business Regulations at the Sub-National Level-A Reform. Implementation Toolkit for Project Teams; International Finance Corporation: Washington, DC, USA, 2006.

58. Donovan, J.; Stoian, D.; Macqueen, D.; Grouwels, S. The Business Side of Sustainable Forest Management: Small and Medium Forest Enterprise Development for Poverty Reduction. 2006. Available online: https://www.researchgate.net/publication/42 764817_The_Business_Side_of_Sustainable_Forest_Management_Small_and_Medium_Forest_Enterprise_Development_for_ Poverty_Reduction (accessed on 10 May 2020).

59. Macqueen, D. Rationale and Tactics for Supporting Small and Medium Forest Enterprises: The Forest Connect Alliance. In Proceedings of the World Forestry Congress, Buenos Aires, Argentina, 19-23 October 2009; pp. 19-23.

60. Fao, R. Community-Based Tree and Forest Enterprise Development (CBED). Market Analysis and Development; Food and Agriculture Organization of the United Nations: Rome, Italy, 2006.

61. De Paula, A.; Scheinkman, J.A. The Informal Sector; 0898-2937; National Bureau of Economic Research: Cambridge, MA, USA, 2007.

62. Levenson, A.R.; Maloney, W.F. The Informal Sector, Firm Dynamics, and Institutional Participation; The World Bank Publications: Washington, DC, USA, 1999.

63. Macqueen, D.J. The Role of Small and Medium Forest Enterprise Associations in Reducing Poverty. A Cut for the Poor. 2006, p. 192. Available online: http:/ /www.fao.org/3/ag131e/ag131e23.htm (accessed on 9 May 2020).

64. Macqueen, D.; Macqueen, D. Supporting Small Forest Enterprises: A Cross-Sectoral Review of Best Practice; IIED Small and Medium Forestry Enterprise Series No.23; IIED: London, UK, 2008.

65. Stoian, D.; Donovan, J.; Poole, N. Unlocking the Development Potential of Community Forest Enterprises: Findings from a Comparative Study in Asia, Africa, Latin America, and the United States. In Proceedings of the XIII World Forestry Congress, Buenos Aires, Argentina, 18-23 October 2009; pp. 18-23.

66. Kambewa, P.; Utila, H. Malawi's Green Gold: Challenges and Opportunities for Small and Medium Forest Enterprises in Reducing Poverty; International Institute for Environment and Development: London, UK, 2008.

67. Macqueen, D.; Team, T.L.-F. Building Profitable and Sustainable Community Forest Enterprises: Enabling Conditions; International Institute for Environment and Development: Edinburgh, UK, 2010.

68. Shaw, P.R.; Bennett, R. Central government support to SMEs compared to business link, business connect and business shop and the prospects for the small business service. Reg. Stud. 1999, 33, 779-787. [CrossRef]

69. Owens, B.P.; Johnson, M.D.; Mitchell, T.R. Expressed humility in organizations: Implications for performance, teams, and leadership. Organ. Sci. 2013, 24, 1517-1538. [CrossRef]

70. Kang, K.-N.; Park, H. Influence of government R\&D support and inter-firm collaborations on innovation in Korean biotechnology SMEs. Technovation 2012, 32, 68-78.

71. Hansen, H.; Rand, J.; Tarp, F. Enterprise growth and survival in Vietnam: Does government support matter? J. Dev. Stud. 2009, 45, 1048-1069. [CrossRef]

72. Conger, J.A.; Kanungo, R.N. The empowerment process: Integrating theory and practice. Acad. Manag. Rev. 1988, 13, 471-482 [CrossRef]

73. Abrar-ul-Haq, M.; Jali, M.; Islam, G. Factors affecting small and medium enterprises (SMEs) development in Pakistan. Am. Eurasian J. Agric. Environ. Sci. 2015, 15, 546-552.

74. Eniola, A.A. The role of SME firm performance in Nigeria. Oman Chapter Arab. J. Bus. Manag. Rev. 2014, 34, 1-15. [CrossRef]

75. Macqueen, D. Doing More to Help SMFEs and their Associations. In United Nations Forum on Forests (UNFF) Side Event on Small Forestry Enterprises: Drivers of Sustainable Development; UNFF: New York, NY, USA, 2007.

76. Mayers, J.; Macqueen, D.; Weng, X.; Tran-Thanh, K. Invest in Forest-Wise People and Business. In Proceedings of the International Learning Event of the China-Africa Forest Governance Platform, Pemba, Mozambique, 23-25 October 2017.

77. Adam, Y.O. The Contribution of Small-Scale Forestry-Based Enterprises to the Rural Economy in the Developing World: The Case of the Informal Carpentry Sector, Sudan. Small-Scale For. 2013, 12, 461-474. [CrossRef]

78. Hobfoll, S.E. Conservation of resources theory: Its implication for stress, health, and resilience. Oxf. Handb. Stress Health Coping 2011, 127, 147.

79. Sigall, H.; Mills, J. Measures of independent variables and mediators are useful in social psychology experiments: But are they necessary? Personal. Soc. Psychol. Rev. 1998, 2, 218-226. [CrossRef]

80. Lawton Smith, H.; Glasson, J.; Chadwick, A. The geography of talent: Entrepreneurship and local economic development in Oxfordshire. Entrep. Reg. Dev. 2005, 17, 449-478. [CrossRef]

81. Smith, H.L.; Bagchi-Sen, S. The research university, entrepreneurship and regional development: Research propositions and current evidence. Entrep. Reg. Dev. 2012, 24, 383-404. [CrossRef] 
82. Schlange, L.E. Stakeholder Identification in Sustainability Entrepreneurship. Greener Manag. Int. 2006, 2006, 13-32. [CrossRef]

83. Eniola, A.A.; Entebang, H. SME managers and financial literacy. Glob. Bus. Rev. 2017, 18, 559-576. [CrossRef]

84. Li, Y.; Zhao, Y.; Tan, J.; Liu, Y. Moderating effects of entrepreneurial orientation on market orientation-performance linkage: Evidence from Chinese small firms. J. Small Bus. Manag. 2008, 46, 113-133. [CrossRef]

85. Li, Y.-H.; Huang, J.-W.; Tsai, M.-T. Entrepreneurial orientation and firm performance: The role of knowledge creation process. Ind. Mark. Manag. 2009, 38, 440-449. [CrossRef]

86. Rezaei, J.; Ortt, R. Entrepreneurial orientation and firm performance: The mediating role of functional performances. Manag. Res. Rev. 2018, 41, 878-900. [CrossRef]

87. Hartsfield, S.; Johansen, D.; Knight, G. Entrepreneurial orientation, strategy, and marketing capabilities in the performance of born global firms. Int. Bus. Res. Teach. Pract. 2017, 2, 12-38.

88. Ali, A. Forest-based livelihoods, income, and poverty: Empirical evidence from the Himalayan region of rural Pakistan. J. Rural. Stud. 2018, 57, 44-54. [CrossRef]

89. Angelsen, A.; Jagger, P.; Babigumira, R.; Belcher, B.; Hogarth, N.J.; Bauch, S.; Börner, J.; Smithhall, C.; Wunder, S. Environmental Income and Rural Livelihoods. World Dev. 2014, 64, S12-S18. [CrossRef] [PubMed]

90. Babulo, B.; Muys, B.; Nega, F.; Tollens, E.; Nyssen, J.; Deckers, J.; Mathijs, E. The economic contribution of forest resource use to rural livelihoods in Tigray, northern Ethiopia. For. Policy Econ. 2009, 11, 109-117. [CrossRef]

91. Bank, W.; Eng, D.C. Sustaining forests. A World Bank strategy. 2003. Available online: http://documents.worldbank.org/ curated/en/424531468781760578/Sustaining-forests-a-development-strategy (accessed on 10 May 2020).

92. Prasanna, R.; Jayasundara, J.; Gamage, N.; Kumara, S.; Ekanayake, E.; Rajapakshe, P.; Abeyrathne, G. Sustainability of SMEs in the Competition: A Systemic Review on Technological Challenges and SME Performance. J. Open Innov. Technol. Mark. Complex. 2019, 5, 100. [CrossRef]

93. Chirico, F.; Salvato, C. Knowledge integration and dynamic organizational adaptation in family firms. Fam. Bus. Rev. 2008, 21, 169-181. [CrossRef]

94. Caglayan, M.; Demir, F. Firm productivity, exchange rate movements, sources of finance, and export orientation. World Dev. 2014, 54, 204-219. [CrossRef]

95. Turyahebwa, A.; Sunday, A.; Ssekajugo, D. Financial management practices and business performance of small and medium enterprises in western Uganda. Afr. J. Bus. Manag. 2013, 7, 3875-3885.

96. Anwar, M.; Ali Shah, S.Z. Managerial Networking and Business Model Innovation: Empirical Study of New Ventures in an Emerging Economy. J. Small Bus. Entrep. 2018, 1-22. [CrossRef]

97. Robson, C.; McCartan, K. Real World Research; John Wiley \& Sons: Hoboken, NJ, USA, 2016.

98. Bell, E.; Bryman, A.; Harley, B. Business Research Methods; Oxford University Press: Oxford, UK, 2018.

99. Davidsson, P. Nascent entrepreneurship: Empirical studies and developments. Found. Trends Entrep. 2006, 2, 1-76. [CrossRef]

100. Delmar, F.; Davidsson, P.; Gartner, W.B. Arriving at the high-growth firm. J. Bus. Ventur. 2003, 18, 189-216. [CrossRef]

101. Hidayat, R.; Akhmad, S. Development of Local-Economic-Development Small and Medium Industries (Led-Sme) In East Java. Makara J. Technol. 2013, 16, 185-191. [CrossRef]

102. Aga, D.A.; Noorderhaven, N.; Vallejo, B. Transformational leadership and project success: The mediating role of team-building. Int. J. Proj. Manag. 2016, 34, 806-818. [CrossRef]

103. Fornell, C.; Larcker, D.F. Structural Equation Models with Unobservable Variables and Measurement Error: Algebra and Statistics; Sage Publications Sage: Los Angeles, CA, USA, 1981.

104. Bagozzi, R.P. “Issues in the application of covariance structure analysis": A further comment. J. Consum. Res. 1983, 9, 449-450. [CrossRef]

105. Sarstedt, M.; Hair, J.F.; Ringle, C.M.; Thiele, K.O.; Gudergan, S.P. Estimation issues with PLS and CBSEM: Where the bias lies! J. Bus. Res. 2016, 69, 3998-4010. [CrossRef]

106. Kline, R.B. Principles and Practice of Structural Equation Modeling; Guilford Publications: New York, NY, USA, 2015.

107. Lu, Y.; Zhou, L.; Bruton, G.; Li, W. Capabilities as a mediator linking resources and the international performance of entrepreneurial firms in an emerging economy. J. Int. Bus. Stud. 2010, 41, 419-436. [CrossRef]

108. Anning-Dorson, T. How much and when to innovate: The nexus of environmental pressures, innovation and service firm performance. Eur. J. Innov. Manag. 2017, 20, 599-619. [CrossRef]

109. Hair, J.F., Jr.; Hult, G.T.M.; Ringle, C.; Sarstedt, M. A Primer on Partial Least Squares Structural Equation Modeling (PLS-SEM); Sage Publications: Thousand Oaks, CA, USA, 2016.

110. Fornell, C.; Larcker, D.F. Evaluating structural equation models with unobservable variables and measurement error. J. Mark. Res. 1981, 18, 39-50. [CrossRef]

111. Xi, M.; Zhao, S.; Xu, Q. The influence of CEO relationship-focused behaviors on firm performance: A chain-mediating role of employee relations climate and employees' attitudes. Asia Pac. J. Manag. 2017, 34, 173-192. [CrossRef]

112. Preacher, K.J.; Hayes, A.F. Asymptotic and resampling strategies for assessing and comparing indirect effects in multiple mediator models. Behav. Res. Methods 2008, 40, 879-891. [CrossRef] [PubMed]

113. Shrout, P.E.; Bolger, N. Mediation in experimental and nonexperimental studies: New procedures and recommendations. Psychol. Methods 2002, 7, 422. [CrossRef] 
114. Carmeli, A.; Tishler, A. The relationships between intangible organizational elements and organizational performance. Strateg. Manag. J. 2004, 25, 1257-1278. [CrossRef]

115. Lusardi, A.; Mitchell, O.S. Financial literacy and retirement planning in the United States. J. Pension Econ. Financ. 2011, 10, 509-525. [CrossRef]

116. Boeker, W. Executive migration and strategic change: The effect of top manager movement on product-market entry. Adm. Sci. $Q$. 1997, 213-236. [CrossRef]

117. Baird, L.; Meshoulam, I. Managing two fits of strategic human resource management. Acad. Manag. Rev. 1988, 13, 116-128. [CrossRef]

118. Lichtenstein, B.M.B.; Brush, C.G. How do "resource bundles" develop and change in new ventures? A dynamic model and longitudinal exploration. Entrep. Theory Pract. 2001, 25, 37-58. [CrossRef]

119. Okello Candiya Bongomin, G.; Mpeera Ntayi, J.; Munene, J.C.; Akol Malinga, C. The relationship between access to finance and growth of SMEs in developing economies: Financial literacy as a moderator. Rev. Int. Bus. Strategy 2017, 27, 520-538. [CrossRef]

120. Storey, D.J. New firm growth and bank financing. Small Bus. Econ. 1994, 6, 139-150. [CrossRef]

121. Ahlstrom, D.; Cumming, D.J.; Vismara, S. New methods of entrepreneurial firm financing: Fintech, crowdfunding and corporate governance implications. Corp. Gov. Int. Rev. 2018, 26, 310-313. [CrossRef]

122. Yang, Y.; Chen, X.; Gu, J.; Fujita, H. Alleviating Financing Constraints of SMEs through Supply Chain. Sustainability $2019,11,673$. [CrossRef]

123. Claessens, S. Access to financial services: A review of the issues and public policy objectives. World Bank Res. Obs. 2006, 21, 207-240. [CrossRef]

124. Wise, S. The impact of financial literacy on new venture survival. Int. J. Bus. Manag. 2013, 8, 30. [CrossRef]

125. Laitinen, E.K. Prediction of failure of a newly founded firm. J. Bus. Ventur. 1992, 7, 323-340. [CrossRef]

126. Windapo, A. Entrepreneurial Factors Affecting the Sustainable Growth and Success of a South African Construction Company. Sustainability 2018, 10, 1276. [CrossRef] 